Etnográfica

Revista do Centro em Rede de Investigação em

Antropologia

vol. $19(3) \mid 2015$

Vol. 19 (3)

\title{
A remarkable congress and a popular general secretary: CIAP/SIEF, Arnhem 1955 and Jorge Dias
}

Um congresso notável e um secretário-geral popular: a CIAP/SIEF, Arnhem 1955

e Jorge Dias

Bjarne Rogan

\section{(2) OpenEdition}

Journals

Electronic version

URL: https://journals.openedition.org/etnografica/4123

DOI: 10.4000/etnografica.4123

ISSN: 2182-2891

\section{Publisher}

Centro em Rede de Investigação em Antropologia

\section{Printed version}

Date of publication: 1 October 2015

Number of pages: 567-576

ISSN: 0873-6561

\section{Electronic reference}

Bjarne Rogan, "A remarkable congress and a popular general secretary: CIAP/SIEF, Arnhem 1955 and Jorge Dias", Etnográfica [Online], vol. 19 (3) | 2015, Online since 28 October 2015, connection on 10 February 2022. URL: http://journals.openedition.org/etnografica/4123 ; DOI: https://doi.org/10.4000/ etnografica. 4123

\section{(c) (i) (8)}

Etnográfica is licensed under a Creative Commons Attribution-NonCommercial 4.0 International License. 


\section{A remarkable congress and a popular general secretary: CIAP/SIEF, Arnhem 1955 and Jorge Dias}

\section{Bjarne Rogan}

The text presents the Commission Internationale des Arts et Traditions Populaires (CIAP), the international organization of ethnology and folklore established in 1928, which was transformed into SIEF - Société Internationale d'Ethnologie et de Folklore - in 1964, thus celebrating its $83^{\text {rd }}$ anniversary in 2011 . The focus is on its congresses, of which there have been close to twenty, although officially not more than ten. Most attention is placed on the 1955 congress in Arnhem, where the newly elected general secretary of CIAP, the Portuguese ethnologist Jorge Dias, was one of the main protagonists. Furthermore, the text briefly discusses Dias' relationship to the organization and to European ethnology and folklore, concluding with some remarks on the future of SIEF and the cumbersome name of the organization.

Um congresso notável e um secretário-geral popular: a CIAP/SIEF, Arnhem 1955 e Jorge Dias - O texto apresenta a Commission Internationale des Arts et Traditions Populaires (CIAP), organização internacional para a etnologia e o folclore estabelecida em 1928 e que viria a transformar-se na SIEF - Société Internationale d'Ethnologie et de Folklore - em 1964, celebrando o seu 83. ${ }^{\circ}$ aniversário em 2011. São analisados os seus quase vinte congressos, embora oficialmente não tenham sido mais de dez. É dada especial atenção ao congresso realizado em Arnhem em 1955, de que um dos principais protagonistas foi o etnólogo português Jorge Dias, secretário-geral recém-eleito da CIAP. É ainda discutida brevemente a relação de Dias com a organização e com a etnologia europeia e os estudos de folclore, concluindo com algumas notas sobre o futuro da SIEF e o nome pouco prático da organização.

ROGAN, Bjarne (bjarne.rogan@ikos.uio.no) - University of Oslo, Norway; Centre franco-norvégien en sciences sociales et humaines, FMSH, Paris. 
DEAR PARTICIPANTS OF THE 10TH SIEF CONGRESS! ${ }^{1}$ I HAVE BEEN ASKED to talk on three topics: (1) the history of the congresses, as we celebrate - plausibly - the $10^{\text {th }}$ congress of the organization; (2) the Portuguese ethnologist Jorge Dias, as the venue of this congress is Lisbon; and (3) the future of SIEF, as the board wants to look forward and not only at our history. The challenge is to combine these themes in a short speech. As it will turn out, however, this combination of themes leads to one or two perhaps unexpected conclusions, with possible consequences for the future.

\section{WHAT IS SIEF?}

If you ask someone what SIEF is, a probable answer would be: congresses and working groups. The congresses have been the backbone of SIEF, and the working groups its more or less agile limbs.

SIEF's working groups, of which there are now nine, are tools for scholarly work, where current debates take place, where one can delve deep into one's special field.

Congresses, on the other hand, serve as meeting places, for contact between the more restricted specialist fields, for updating on global issues, sometimes also for confrontations, and - at their best - as opportunities for a better grasp of the discipline as a whole.

With more than 80 years without a scholarly journal of our own, except for a few issues of Laos in the 1950s, the internal exchange has - until recently been a challenge to the octogenarian SIEF. This state of affairs has made the congresses all the more important.

I said octogenarian. And I said the 10th congress. How old are we actually? And how many congresses have we arranged? That depends on how we interpret our history and on how we count.

It is a myth that the switch from CIAP to SIEF in 1964 represented a break. What happened in 1964 was a change of name (and not the first one in our history), and a change of by-laws (but only one of many such changes). SIEF is now 83 years old and more vital than ever. I look forward to its centennial congress.

SIEF is the longest-living general organization for European ethnology. Its roots go back to October, 1928, when the League of Nations organized a congress on "les arts populaires" - folk art - in Prague. Out of this congress, and against the will of the politicians of the League, a new organization was born

1 This text was originally presented as the inaugural keynote address at SIEF's 10th Congress, Lisbon, April 17th, 2011. It is based on research in the following archives: Museu Nacional de Etnologia, Lisbon; Musée National des Arts et Traditions Populaires (MNATP/MuCEM), Paris; Nordiska Museet, Stockholm; and Meertens Instituut, Amsterdam. 
- CIAP, or Commission Internationale des Arts Populaires (Rogan 2014). The scholars wanted it to be a scholarly society, whereas the politicians wanted it to be a tool for cultural action, to promote peace and mutual understanding. CIAP did not fulfill any of these goals in the inter-war years. One reason was political circumstances, with the rising regimes of Nazism, Fascism and Communism; another, the weak university basis of the disciplines.

\section{BREAK OR CONTINUITY?}

Let us stick to the question of break or continuity. The 1964 General Assembly of CIAP in Athens was a dramatic event, resulting in new by-laws and a new name - SIEF. But there can be no doubt that SIEF was a direct continuation of CIAP. The transformation into SIEF meant that a new group of scholars, led by the German folklorist Kurt Ranke, took command of the old organization, which had for some time been dominated by Nordic scholars: by a Norwegian elected president, Reidar Th. Christiansen, and a Swedish de facto president - Sigurd Erixon (Rogan 2008b).

The schism was due to more than rivalry between individual scholars. Several issues were at stake, such as membership policies and adherence to the UNESCO system. An important factor was the very strained relationship at the time between folklorists and ethnologists. The folklorists who took over wanted to stress the independence of the sub-disciplines and a clear division of labor through the name of SIEF: that is, ethnology and folklore. The ethnologists, and those who regarded the discipline as a unified one covering both fields, withdrew and established their own network, with the new journal Ethnologia Europaea. Among the latter we find the Swede Sigurd Erixon, the Yugoslav Branimir Bratanić, the Dutchman Pieter J. Meertens and the Portuguese Jorge Dias (Rogan 2008b).

The new SIEF leaders as of 1964 took care to stress the continuity and the fact that the new "society" had inherited all the assets of the old "commission" - that is, tangible as well as intangible assets, real as well as symbolic: not only the archives and the treasury (which, by the way, was empty), but the working groups and the affiliation to UNESCO as well. But they wanted to signal a rejuvenation of the organization through the new name - SIEF. A new name was a powerful symbol to rebrand an old organization.

However, the new SIEF regime from 1964 did not manage to launch a journal, and the most important working group, the atlas and cartography commission, ended up as an independent organization - the Ständige internationale Atlaskommission (Rogan 2013).

The efforts to arrange congresses were no more successful. During the following 18 years - that is, the presidencies of the Belgian Karel Peters and the Romanian Mihai Pop - SIEF organized only two congresses, one in Paris in 
1971 and one in Suzdal, in Russia, in 1982. So one might say, ironically, that during the first 20 years SIEF did in all respects represent a faithful continuation of CIAP, and no rejuvenation.

\section{COUNTING CONGRESSES}

During its 36 years of existence, CIAP had held only three congresses with venues in Prague, in 1928; Antwerp, in 1930; and Paris, in 1947. That is formally, as other important CIAP congresses, like Stockholm, in 1951, and Arnhem, in 1955, were not counted. For several reasons CIAP was unable to organize anything after 1955. So one of the main goals of the new SIEF in 1964 was to revive the congress tradition. However, it took another seven years before Jean Cuisenier finally ventured to host the first congress in Paris.

But this Paris congress in 1971, was it really a SIEF congress? It was organized by the ethnological and the anthropological museums in Paris. But SIEF never appeared in the name of the congress. It should be remembered that after World War II the French have continually tried to omit the term folklore. So the French decided that the official name of the congress should be "The lst Congress of European Ethnology."

If we take another look back, we can observe a striking parallel to the most important CIAP congresses. They were named congresses of ethnology, with an invitation to CIAP to host its general assemblies. When Sigurd Erixon arranged a CIAP congress in Stockholm in 1951, it was officially named "International Congress of European and Western Ethnology." When the Dutchman Winand Roukens arranged a CIAP congress in Arnhem in 1955, it was named "Congrès International d'Ethnologie Régionale" - with no mention of CIAP.

It was not until 1982, in Russia, that the name of SIEF was used officially for the congress. Still, in his presidential address, Jean Cuisenier (president in function, as the Romanian Pop had withdrawn) insisted upon calling it the " 2 nd Congress of European Ethnology." Only in 1987, when the following congress was organized in Zurich during the presidency of Nils-Arvid Bringéus, the unequivocal name was "SIEF's Third Congress."

The rest may be told in few words. Every third or fourth year there has been an official SIEF congress, in Bergen, Vienna, Amsterdam, Budapest, Marseille, Derry, and now Lisbon. SIEF has been on the rails since the late 1980s, with regular and well attended congresses.

\section{THE INVENTION OF A TRADITION}

So what, you may ask. Are we the 10th congress, or perhaps only the 8th, or - considering the organic continuity with CIAP - perhaps number 16 or 
18? How one counts congresses is culture as much as algebra. This is not so important, and I hope you will forgive me this act of deconstruction. I will argue for continuity in years: SIEF is the oldest international organization of its kind, actually 83 years old. I would likewise argue for a relaxed attitude to the counting of congresses: the present one may very well be called the 10th. It is not quite true, nor is it a direct lie. It's just a question of interpretation and the invention of traditions.

There are perhaps several reasons for the inexact counting. Let me mention a few. One reason was that several conveners wanted to stay clear of the term folklore. Another was that both the League of Nations, and later UNESCO - as long as we depended on their meager allocations - disliked these scholarly international congresses, unless they could supervise them closely. So in order not to provoke the international benefactors, it was safer to omit the name of the organization and give the congresses titles that corresponded to the hosting country's conception of the discipline.

\section{A LOOK BACK AT THE MID-20 ${ }^{\mathrm{TH}}$ CENTURY CONGRESSES}

The present congress takes place in Portugal. I must remind you of the fact that our most popular general secretary ever was Portuguese: Jorge Dias. He was active in CIAP in the 1950s and in SIEF in the 1960s. To give him the honor he deserves, and because the most interesting congress in our history took place under his supervision, I will turn for a moment to the mid-century congresses.

The form and content of the congresses have changed much over the years. Thematically, the earliest ones were rather unstructured events where participants gave plenary lectures on what they had on their minds and hearts. For instance, the 1947 congress in Paris was a rather unbridled event, marked by a naive post-war optimism concerning ethnology's role in the reconstruction of a war-ridden Europe.

Later congresses have been thematically more restricted. The real change came in Arnhem in 1955, where the theme was European ethnology as a scholarly discipline, its definition and delimitation, its unity and its name. The themes were narrowed down, with the 1987 Zurich congress as the most sharply delimited one ("The life cycle"), and then widened up again, with Derry 2008 and Lisbon 2011 as examples of broad topics where all may find their slots and niches - with themes like "Liberating the ethnological imagination" and "People make places."

This trend is related to membership policy and the number of participants. Earlier congresses were reserved for invited scholars only. As late as in Zurich in 1987 only officially-appointed SIEF members were invited, together with the editorial board of Ethnologia Europaea and a selection of specialists on 
the chosen topic. From 1990, however, SIEF congresses have been open to everyone.

There are other differences, more amusing than scholarly, like the dress code. For the 1955 Arnhem congress, Winand Roukens sent a missive to the delegates, informing them - in three languages - that they were expected to wear a Sunday-best-suit (Sonntagsanzug, costume de dimanche). I wonder if this spirit of Arnhem is still alive among today's participants... And Roukens obviously wanted to see people well shaven, informing everyone who would bring electric razors that the voltage was 220 in the Netherlands.

\section{THE FIRST MODERN CONGRESS: ARNHEM 1955}

Apart from these oddities, the Arnhem congress in the Netherlands was the first modern congress (AAVV 1956). The handpicked lecturers were admonished to deal with problems concerning "the essence of the science" and "the present state of affairs", and to "arrive at tangible results." Nothing less than that! Compared to earlier congresses, the Arnhem event represented modernity: a better-targeted topic, fewer and shorter plenary lectures, summaries distributed beforehand, and prepared comments. And there was a direct follow-up session in Amsterdam, for a handpicked group of 13 scholars (Rogan 2008a, 2013).

Much of this must be attributed to the Dutch hosts, who issued invitations on behalf of the Dutch Academy of Sciences. But it was CIAP's general secretary Jorge Dias who was the motive power behind the scholarly program, in cooperation with Sigurd Erixon and Pieter J. Meertens. This program was quite revolutionary, compared to the earlier congresses. Topics treated were the position of folklore and ethnology in society, their relative regression, their relationship to other disciplines in the humanities and the social sciences, and, not least, the unity of folklore, ethnology and anthropology. There were strong arguments for four measures to be taken: a stronger focus on the social dimension, to pay more attention to contemporary issues and less to history, to acknowledge the unity of the discipline and to give it an internationally acceptable name - like "regional ethnology" - and to regard it as a sub-discipline of general ethnology or anthropology.

The most noteworthy contribution came from Jorge Dias, with his well-argued analysis of European ethnology and its relationship to general ethnology (Dias 1956). However, the conclusions and proposals of the congress were never followed up. The more traditional folklorists preferred to see their field as a separate discipline, and the German-speaking community refused to bid farewell to the term Volkskunde.

The time was not yet ripe for a settlement with the Nazi past of the discipline. But a remarkable event during the congress was the confrontation with 
the communist oppression of East European scholars, as in the controversy between the Baltic refugee Oskar Loorits and "der rote Volkskundler" Wolfgang Steinitz, from Berlin (Rogan 2013).

There has hardly been a congress in our discipline that has been so marked by self-reflexivity and filled so many scholars with optimism for the future of the discipline. The Arnhem-Amsterdam congress has been referred to as the most blissful moment of European ethnology. Still, the long-term results were modest. No unity of the disciplines was obtained, nor any consensus about its name. These issues should haunt CIAP in the following years and split its members, as seen in 1964 when CIAP became SIEF.

\section{THE NEW GENERAL SECRETARY: ANTÓNIO JORGE DIAS}

Who was this man, António Jorge Dias (1907-1973), who revived CIAP in 1955 and gave hope of a better ethnological future in Europe? Dias was professor in cultural anthropology, first in Coimbra, later in Lisbon. His early fieldwork was in Portugal, on social and material culture. His later research focused on Africa. He was the only Europeanist in the CIAP setting with research experience from other parts of the world. An additional qualification was his fluency in all major European languages - German, French, and English, in addition to Portuguese and Spanish.

Dias had his qualms when he took over as general secretary of CIAP in July, 1954. The preceding general secretary had just been forced to withdraw because of allegations of embezzlement, and CIAP lay in ruins. Only two national committees were active, the Dutch and the Swedish, and his first task was to reestablish these pillars of CIAP. He wrote letters and reminders to countries all over the globe, to establish national CIAP committees. He wrote an incredible volume of letters to the UNESCO authorities, for the economic survival of CIAP. Dias complained many times of a bureaucratic burden that

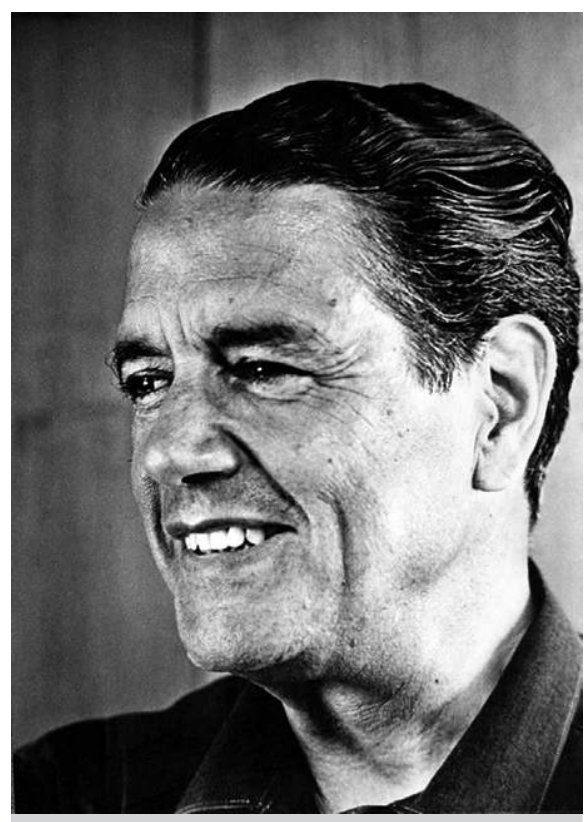

Figure 1

António Jorge Dias (1907-1973). Portuguese ethnologist/anthropologist, general secretary of CIAP in 1954-1957, partisan of a rival society of regional ethnology in the 1960s, founding member of the journal Ethnologia Europaea in 1967. 
almost killed him, on top of his duties in Lisbon and in the Portuguese colonies and provinces overseas.

Among Dias' visions for CIAP was that it should be a worldwide organization, not only a European one. Another, which he repeated time and again, was that CIAP should embrace a unified discipline of "regional ethnology" or "cultural anthropology." He could not accept the descriptive ethnography of the day, and he looked to anthropology for a theoretical basis. He detested the territorial claims of some ethnographers and especially folklorists, who claimed a division of labor and separate disciplines.

He wanted to escape from what he used to call "the scholarly provincialism" of many colleagues in Portugal. To his disappointment he met much of the same in CIAP in the 1950s and in SIEF in the 1960s. He complained to Sigurd Erixon and Georges-Henri Rivière about the "narrow conception" of the discipline among many of the folklorists. He wanted to use CIAP, and especially the Arnhem congress, "to fight" for "a radical transformation of this present state of things" (quoted from his letters). His guiding stars were Marcel Maget and Sigurd Erixon, and he kept close contacts with Branimir Bratanić in Zagreb, Peter J. Meertens in Amsterdam, and later with Geza Csermak-Rohan in Paris, who all shared his vision of a unified discipline of regional ethnology. Actually it was Dias who first proposed a rival organization for European ethnology, in 1964, when CIAP was taken over by the folklorists under the name of SIEF. Being a pragmatist he joined the SIEF board for a short time, to which he was elected in absentia in Athens, but he preferred to work for a new organization.

As for his period in CIAP, he met with disappointment after disappointment after the Arnhem congress. What formally provoked his resignation from his position as general secretary in the spring of 1957 was his appointment as leader of a four-year research program in the Portuguese colonies. But at the bottom lay his disappointment with the stagnation of CIAP, combined with the bureaucratic burden. CIAP's president, the Norwegian Reidar Th. Christiansen, was always absent, and when the treasurer of CIAP, the Swiss Ernest Baumann, died, he threw in the sponge and resigned in 1957.

More could be said about Dias and his work in the cartography commission, for a rival ethnological organization in the mid-1960s, and for the journal Ethnologia Europaea. But that's another story.

\section{TO RESUME AND CONCLUDE}

There has hardly ever been a European ethnologist who has enjoyed a more widespread popularity than did Jorge Dias. Dias combined scholarship, visions for the discipline and charisma, to which should be added his fluency in the main European languages. Even in the difficult 1960s, when Dias sided with 
the Erixonian camp, there were some in the opposite camp who wanted him as president of the new SIEF.

Dias' vision was to use CIAP, and later SIEF (or preferably an alternative society), for the promotion of a unified discipline of cultural anthropology. As he wrote repeatedly in his letters, his travels to South America and Africa made scales fall from his eyes as a Europeanist.

His disappointments were many. Suffice it to mention the disciplinary territorial claims of many of his contemporaries, their "excessive love of the local and the particular," and the claims of independence for their specialties - problems which he attributed to the weak university basis of the discipline(s).

I have been asked by the Board to add a few words on the future of SIEF. That's a risky exercise. But as an act of homage to Dias, I will borrow one of his main arguments. In his spirit, we must acknowledge that the stake is not SIEF in itself, but what SIEF can do for the discipline. The university basis of the discipline is perhaps better today than in the days of Dias. But at the same time it is seriously threatened by cuts and mergers. Small sector disciplines are left with small chances of survival in today's university landscape. In my eyes, the future lies in stronger, consolidated university departments for culture studies, or whatever you want to call it. If SIEF wants to support a strengthening of the field, SIEF should first of all seriously reconsider its outdated (excuse the expression) name, a name that Dias strongly disliked. This name was a bone of contention already in 1964, and it still is an obstacle to potential supporters. "Ethnology" and "folklore" are no longer good currency in present-day university politics in most countries. If we should make a strategic move, the time is more than ready for a new change of name of the organization.

Jorge Dias would probably have proposed "cultural anthropology," or "European" or "regional ethnology," for a new name. It is not up to me to propose a common denominator for the name of the organization. We have changed our name once - or actually twice, as the expression "et Traditions" was added to the name in 1936, as the scholars wished to signal a broader field of interest than the "folk art commission" that the politicians had wanted CIAP to be. We can do it again. Nothing prevents us from changing the name a third time. Jorge Dias would certainly have applauded such a decision.

So, ladies and gentlemen: the heritage from our most popular general secretary and our most thrilling congress ever should be taken seriously. That is, the spirit of the congress, of course, and not the form. There will be no control of your dress tonight. Nor will there be any check tomorrow whether the gents have shaved.

I wish you all an inspiring congress. Thank you! 


\section{REFERENCES}

AAVV, 1956, Actes du Congrès International d'Ethnologie Régionale, Arnhem 1955. Arnhem, Het Nederlands Openluchtmuseum.

DIAS, Jorge, 1956, "The quintessence of the problem: nomenclature and subject-matter of Folklore", in AAVV, Actes du Congrès International d'Ethnologie Régionale. Arnhem, Het Nederlands Openluchtmuseum, 1-14.

ROGAN, Bjarne, 2008a, "The troubled past of European Ethnology: SIEF and international cooperation from Prague to Derry", Ethnologia Europaea, 38 (1): 66-78.

ROGAN, Bjarne, 2008b, "From CIAP to SIEF: visions for a discipline or power struggle?", in M. N. Craith, U. Kockel and R. Johler (eds.), Everyday Culture in Europe: Case Studies and Methodologies. London, Ashgate, 61-100.

ROGAN, Bjarne, 2013, "Sigurd Erixon on the post-war international scene: international activities, European Ethnology and CIAP from 1945 to the mid 1950s", in Arne Bugge Amundsen (ed.), Arv: Nordic Yearbook of Folklore 2013. Uppsala, The Royal Gustavus Adolphus Academy, 89-152.

ROGAN, Bjarne, 2014, "Popular culture and international cooperation in the 1930s: CIAP and the League of Nations", in M. Herren (ed.), Networking the International System: Global Histories of International Organizations. Berlin and Heidelberg, Springer, 175-185. 